\title{
Adsorptive Performance of Congo Red using Copper-Aluminum LDHS Load to Rice Husk Biochar
}

(Prestasi Penjerapan Kongo Merah menggunakan Beban Tembaga-Aluminium LDHS kepada Bioarang daripada Sekam Padi)

\author{
Neza Rahayu Palapa, Novie Juleanti, Normah, Tarmizi Taher, Risfidian Mohadi, AdDy Rachmat \& \\ ALDES LESBANI*
}

\begin{abstract}
This work aimed that CuAl layered double hydroxide (LDH) is loaded to biochar to form CuAlLDH@BC composites by co-precipitation methods.CUAlLDH@BC composite was prepared and characterized by X-ray diffraction (XRD), Fourier transform infrared (FTIR) spectroscopy, surface area specific analysis BET method, thermalgravimetric, and scanning electron microscopy (SEM) for morphological analysis.CUAlLDH@BC composite used as adsorbent for the removal of Congo red. The adsorption ability of CuAlLDH@BC composite evaluated by pseudo-second-order kinetic model, with $Q e_{\text {calculated }}$ and $Q e_{\text {experimental }}$ of the composite were closed (47.619 and $46.143 \mathrm{mg} / \mathrm{g}$, respectively). Furthermore, the adsorption conducts were more consistent with the Langmuir isotherm model, than the Freundlich isotherm model. The isotherm adsorption data obtained the maximum adsorption capacity was $61.350 \mathrm{mg} / \mathrm{g}$. Thermodynamic studies illustrated the endothermic nature of CuAlLDH@BC, as well as the fact that the adsorption process is spontaneous. Thus, CuAlLDH@BC showed a high reusability performance even after third cycle of adsorption-desorption process.
\end{abstract}

Keywords: Adsorption; biochar; composite; congo red; layered double hydroxide

\section{ABSTRAK}

Kajian ini bertujuan supaya hidroksida berganda berlapis CuAl (LDH) dimuatkan ke bioarang untuk membentuk kompositCuAlLDH@BC melalui kaedah kerpasan bersama.KompositCuAlLDH@BC telah disedia dan dicirikan oleh pembelauan sinar-X (XRD), spektroskopi inframerah transformasi Fourier (FTIR), kaedah BET analisis khusus luas permukaan, gravimetrik terma dan mikroskop elektron pengimbasan (SEM) untuk analisis morfologi. KompositCuAlLDH@ BC digunakan sebagai penjerap untuk penyingkiran merah Kongo. Keupayaan penjerapan komposit CuAlLDH@BC dinilai oleh model kinetik kedua pseudo dengan $Q e_{\text {calculated }}$ dan $Q e_{\text {experimental }}$ komposit telah ditutup (masing-masing 47.619 dan $46.143 \mathrm{mg} / \mathrm{g}$ ). Tambahan pula, kelakuan penjerapan lebih tekal dengan model isoterma Langmuir, berbanding model isoterma Freundlich. Data penjerapan isoterma memperoleh kapasiti penjerapan maksimum ialah $61.350 \mathrm{mg} / \mathrm{g}$. Kajian termodinamik menggambarkan sifat endotermikCuAlLDH@BC serta hakikat bahawa proses penjerapan adalah spontan. Oleh itu, CuAlLDH@BC menunjukkan prestasi kebolehgunaan semula yang tinggi walaupun selepas kitaran ketiga proses penjerapan-desorpsi.

Kata kunci: Bioarang; hidroksida berganda berlapis; komposit; Kongo merah; penjerapan

\section{INTRODUCTION}

Synthetic dye wastewater is considered to be an environmental hazard that can contaminate water for a long time (Ma et al. 2015). The major sources of synthetic dye in wastewater are the textile, paper, pulp, paint, and cosmetic industries (Schwarzenbach et al. 2010). Commonly, synthetic dyes such as Congo red have a high resistance to oxidizing agents, are non-biodegradable, highly toxic, and an eye and skin irritant. Congo red dye is diazo- benzidine-based anionic dye. Congo red become popular as synthetics dye due to a bright color, does not wear off easily, sold freely for textile industry and after use carelessly thrown away without any treatments (Raval et al. 2016). Therefore, the elimination of Congo red from wastewater has become a necessity (Chakraborty \& Nagarajan 2015). Techniques including adsorption (Soleimani et al. 2018), bioremediation (Vikrant et al. 2018), chemical decomposition (Gholami et al. 2020), and membrane (Shenvi et al. 2015) have been used to remove dyes from aqueous solutions. Based on its cost- 
effectiveness, ease of use, and high efficiency, adsorption is considered to be the leading technique for the removal of pollutants in water. Potential adsorbents include bentonite (Mohammed \& Baytak 2016), zeolite (Abdelrahman 2018), activated carbon (Foroutan et al. 2019), and layered double hydroxide (LDH) (Lesbani et al. 2020).

LDH is an anionic-synthetic layered material which can be used as an adsorbent due to its highly flexible structure. The general formula of LDH is [M2+1-xM3+ $\mathrm{x}(\mathrm{OH}) 2] \mathrm{x}+[\mathrm{Amx} / \mathrm{m} \cdot \mathrm{nH} 2 \mathrm{O}] \mathrm{x}-$, where $\mathrm{M} 2+$ is a divalent cation, M3+ is a trivalent cation, and Am is an interlayer anion (Wu et al. 2011). Its strong adsorption performance can be attributed to anion exchange from the interlayer. LDH can be synthesized in some ways, including precipitation, hydrothermal synthesis, and ion exchange. It can adsorb various pollutants from wastewater, including metal cations, dyes, and organic compounds. Palapa et al. (2020a) reported that $\mathrm{CuCr}-\mathrm{LDH}$ adsorbed malachite green with a maximum uptake of $56 \mathrm{mg} / \mathrm{g}$. Furthermore, Zhu et al. (2020) reported that a MgAl-LDH nanostructure could remove organic contaminants, such as non-ionic naphthalene, to a maximum capacity of $43.7 \mathrm{mg} / \mathrm{g}$, while Tran et al. (2018) found that MgAl-LDH adsorbed copper and lead in an aqueous solution with a maximum uptake of 84.7 and $59.9 \mathrm{mg} / \mathrm{g}$, respectively. However, LDH powder has a limited adsorption capability due to its tight layer stacking (Inumaru et al. 2007). Researchers have attempted to improve the adsorption capabilities of LDH using intercalation (Lesbani et al. 2020), composite (Malak-Polaczyk et al. 2010), and calcination (Peng et al. 2015) processes. According to Mahjoubi et al. (2017), Ni-CLDH calcined have good adsorption capacity up to $438 \mathrm{mg} / \mathrm{g}$ for malachite green removal. The intercalation process of $\mathrm{CuAl} \mathrm{LDH}$ by polyoxometalate was enhancing adsorption capacity malachite green removal from 55.866 to $149.253 \mathrm{mg} / \mathrm{g}$ (Palapa et al. 2020a). However, in this era, the modification material using carbon enrichment has become the preferred choice due to its high surface area, stable structure, and effectiveness as a supporting material (Cui et al. 2020). On the other hand, the utilization of carbonaceous from waste biomass is a new reuse method of waste management (Firdaus et al. 2017). Biochar (BC) is a carbon-based compound produced by the pyrolysis of biomass at high temperatures. $\mathrm{BC}$ is an attractive carbon-rich material from agricultural waste and industrial byproducts that can be used in material modification (Xia et al. 2019). According to Huang et al. (2019) reported that LDH modified with BC can enhance adsorption capacity of dyes. Meili et al. (2019) reported that the MgAl LDH modified by $\mathrm{BC}$ from an animal's bone had been used to remove methylene blue from water solution. The maximum adsorption capacity attains $406 \mathrm{mg} / \mathrm{g}$. Wang et al. (2016) also reported that the removal of Ar using NiFe modified by $\mathrm{BC}$ from pine has a maximum adsorption capacity of $438 \mathrm{mg} / \mathrm{g}$. Zubair et al. (2020) reported that date palm BC loaded to MgAl-LDH were employed for enhanced aqueous uptake of methylene blue $302.75 \mathrm{mg} / \mathrm{g}$ after 180 min. Accordance with previous studies showed that LDH modified using $\mathrm{BC}$ has good potential, effectivity and high performance as adsorbent.

In this study, CuAl-LDH was developed as a composite with $\mathrm{BC}$ to enhance the adsorption efficiency of Congo red in an aqueous solution. We evaluated the kinetic and thermodynamic parameters of the adsorption process by varying time, temperature, and initial concentration. The reusability of the adsorbent was studied using three cycles of adsorption-desorption using several reagents.

\section{MATERIALS AND METHODS}

\section{CHEMICALS AND INSTRUMENTATIONS}

The analytical grade chemicals used in this study included copper nitrate (99.5\%, $241.60 \mathrm{~g} / \mathrm{mol}$, Merck), aluminum nitrate $(95.0 \%, 375.13 \mathrm{~g} / \mathrm{mol}$, Merck $)$, sodium hydroxide (99.9\%, $40.0 \mathrm{~g} / \mathrm{mol}$, Sigma Aldrich), and sodium carbonate $(99.9 \%, 105.99 \mathrm{~g} / \mathrm{mol}$, Merck). Rice husk biochar was obtained and used as received from a local supplier with pyrolysis treatment in a furnace under constant $\mathrm{N}_{2}$ flow for two hours at $500{ }^{\circ} \mathrm{C}\left(10{ }^{\circ} \mathrm{C} /\right.$ $\mathrm{min})$. The Congo red (CR) solutions were prepared by dissolving the calculated amounts of CR into deionized water. The X-ray diffraction (XRD) characterization was performed using XRD Rigaku Miniflex-600 and the sample was measured at a scan rate of $1 \% \mathrm{~min}$. Infrared spectra were obtained from FTIR Shimadzu Prestige-21 measurements using a $\mathrm{KBr}$ disc and the samples were scanned at wavenumber $400-4000 \mathrm{~cm}^{-1}$. The specific surface area was calculated using Multipoint BrunauerEmmett-Teller (BET) based on data collected by ASAP Micromeritics 2020 at $77 \mathrm{~K}$. The surface morphology of materials was characterized using a scanning electron microscope (SEM) Quanta-650 Oxford instrument. The thermogravimetric curve was determined using a Shimadzu DTG-60H instrument. The dye concentration was analyzed using a UV-visible spectrophotometer BioBase BK-UV1800 at a $498 \mathrm{~nm}$ wavelength of maximum absorbance.

\section{PREPARATION OF CUALLDH@BC}

The CuAl-LDH starting material was obtained as per Palapa et al. (2020b). The preparation of CuAl-LDH loaded 
by BC to form CuAlLDH@BC was conducted using coprecipitation method. A solution of copper nitrate $10 \mathrm{~mL}$ $0.75 \mathrm{M}$ was mixed with $10 \mathrm{~mL} 0.25 \mathrm{M}$ aluminum nitrate. The mixture was stirred at a constant rate for an hour until the starting materials were completely dissolved. A beaker containing $1 \mathrm{~g}$ of the biochar was prepared and added to the mixture with continuous stirring. A solution of $1 \mathrm{M}$ sodium hydroxide was added dropwise until a $\mathrm{pH}$ of 10 was reached. The mixing solution was kept at $80^{\circ} \mathrm{C}$ for three days. Composites were then washed and dried at room temperature for a day.

\section{ADSORPTION EXPERIMENTS}

The adsorption process was carried out in batch systems. A $50 \mathrm{mg}$ of adsorbents was added into 50 $\mathrm{mL} C \mathrm{CR}$ solution with various initial concentration. The adsorption process was conducted by variation of adsorption time, and temperature. As much as $0.05 \mathrm{~g}$ adsorbents (i.e. CuAl LDH, BC and CuAlLDH@BC) was added into $0.05 \mathrm{~L} \mathrm{CR}$ solution, respectively, with various concentration $50-90 \mathrm{mg} / \mathrm{L}$ and shaken for $5-150 \mathrm{~min}$ at temperature $303-333 \mathrm{~K}$. The desorption study was performed using several reagents, including $\mathrm{NaOH}$, $\mathrm{HCl}$, water, and ethanol. The adsorbed material (0.250 g) and reagent $(25 \mathrm{~mL})$ were mixed and the mixture was shaken for $180 \mathrm{~min}$. The filtrate was separated by centrifugation at $100 \mathrm{rpm}$ and measured using UV-Vis spectrophotometer. The reusability was carried out under optimal condition obtained from adsorption studies in batch adsorption. As much as $0.250 \mathrm{~g}$ of CuAlLDH@ $\mathrm{BC}$ composite was added into $100 \mathrm{~mL}$ of CR with concentration $100 \mathrm{mg} / \mathrm{L}$ within $2 \mathrm{~h}$ at $30{ }^{\circ} \mathrm{C}$. Then, the
CuAlLDH@BC was collected, washed by deionized water, dried at $90{ }^{\circ} \mathrm{C}$ for $1 \mathrm{~h}$ and reuse as adsorbent. The reusability of CuAlLDH@BC was examined by the repetition of $\mathrm{CR}$ adsorption for three cycles. Similar procedure was conducted using $\mathrm{CuAl} \mathrm{LDH}$ and $\mathrm{BC}$ for reusability study.

\section{RESULTS AND DisCUSSION}

\section{CHARACTERIZATION OF MATERIALS}

The Fourier-transform infrared spectroscopy (FTIR) spectrum and XRD pattern of CuAl-LDH, BC, and the CuAlLDH@BC composite are shown in Figure 1. The broad vibration of hydroxyl groups (O-H stretching) in brucite layers and the interlayer was confirmed at 3420 $\mathrm{cm}^{-1}$ for both LDH samples. The lower vibration at 1635 $\mathrm{cm}^{-1}$ was attributed to $\mathrm{O}-\mathrm{H}$ bending. The nitrate anion from the CuAl-LDH and CuAlLDH@BC interlayer was confirmed by an intense peak at $1381 \mathrm{~cm}^{-1}$. The $\mathrm{BC}$ spectra shows a low intense peak that denotes the stretching vibration of $\mathrm{C}-\mathrm{O}$ at $1645 \mathrm{~cm}^{-1}$. The FTIR spectrum of both BC and CuAl-LDH appears in the CuAlLDH@BC composite and indicates that the composite material was successfully prepared. Figure 1 also shows the powder diffractogram of adsorbents. The CuAlLDH@ $\mathrm{BC}$ diffractograms are composed of the characteristic diffraction pattern for CuAl-LDH and BC.CuAlLDH@ BC show peaks at $10^{\circ}, 28^{\circ}, 35^{\circ}$, and $60^{\circ}$ corresponding to reflections from (003), (006), (012), and (110), indicating that the material has a layered structure. The broad peak at $24^{\circ}$ corresponds to the reflection plane (002) on the surface of the LDH due to the presence of BC. The interlayer space of the CuAlLDH@BC composite was $7.66 \AA$.
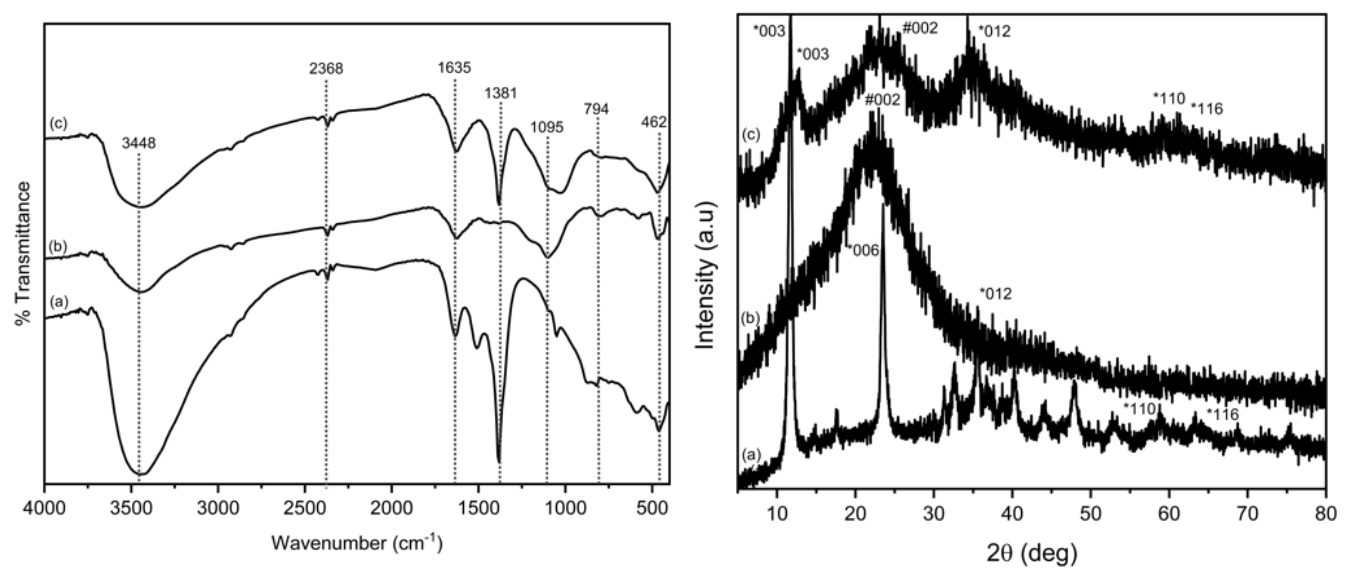

FIGURE 1. FTIR spectra and XRD pattern of (a) $\mathrm{CuAl} \mathrm{LDH,} \mathrm{(b)} \mathrm{BC,} \mathrm{(c)} \mathrm{CuAl-}$ LDH@BC composite 
The nitrogen adsorption-desorption isotherms of CuAl-LDH, BC, and CuAlLDH@BC are shown in Figure 2. The nitrogen adsorption-desorption curve indicates type IV, indicating a mesoporous material. The hysteresis loop of the materials is H3-type, consistent with a cavitationinduced desorption branch lower limit of $(P / P o)>0.42$. The H3 hysteresis explains the binding strength of anions located in the interlayer. Table 1 shows the BET surface areas, pore-volume, and pore size of CuAl-LDH, BC, and CuAlLDH@BC.According to IUPAC classifications, the pore size of CuAlLDH@BC can be characterized as mesopore (Thommes et al. 2015). The surface area of CuAlLDH@BC according to the BET calculation is 200.9 $\mathrm{m}^{2} / \mathrm{g}$. Although the pore size of the composite is lower than CuAl-LDH, its pore volume increased three-fold. The decrease in pore size can be attributed to the loading of biochar into layers and the LDH surface. Azargohar and Dalai (2006) reported that carbon rich BC possesses no pores and has a low surface area.

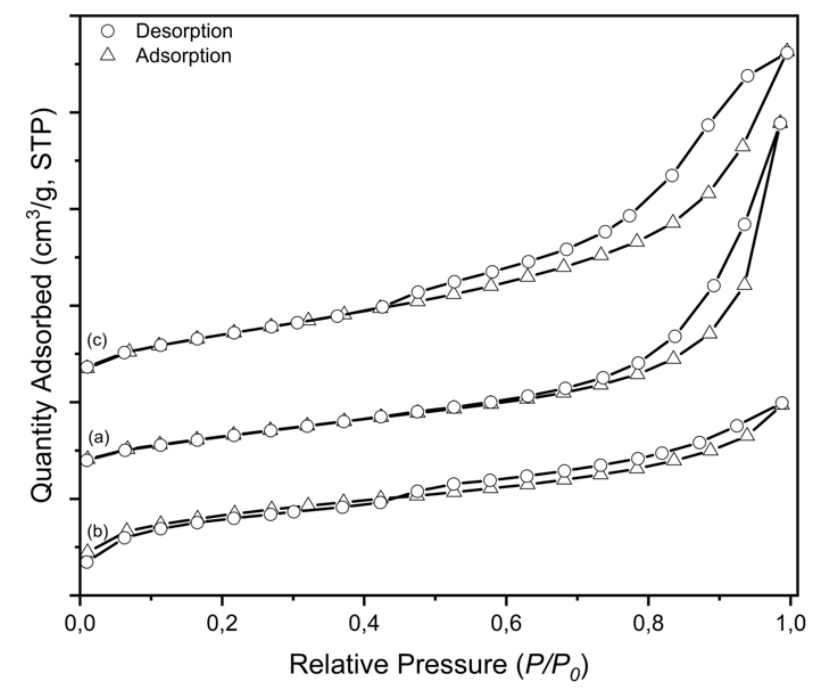

FIGURE 2. $\mathrm{N}_{2}$ adsorption-desorption curve of (a) $\mathrm{CuAl} \mathrm{LDH,} \mathrm{(b)} \mathrm{BC,} \mathrm{(c)} \mathrm{CuAl-}$ LDH@BC composite

TABLE 1. BET calculation results of $\mathrm{LDH}$ and $\mathrm{BC}$ adsorbents

\begin{tabular}{lccc}
\hline \multicolumn{1}{c}{ Adsorbents } & $\begin{array}{c}\text { Pore volume } \\
\mathrm{cm}^{3} / \mathrm{g}\end{array}$ & $\begin{array}{c}\text { BET surface } \\
\mathrm{m}^{2} / \mathrm{g}\end{array}$ & $\begin{array}{c}\text { Pore size } \\
\mathrm{nm}\end{array}$ \\
\hline $\mathrm{CuAl}$ LDH & 0.116 & 46.2 & 10.39 \\
$\mathrm{BC}$ & 0.060 & 72.25 & 3.33 \\
$\mathrm{CuAlLDH} @ \mathrm{BC}$ & 0.350 & 200.90 & 7.03 \\
\hline
\end{tabular}

The thermogravimetric curves of CuAl-LDH, BC, and CuAlLDH@BC precursors shown in Figure 3 have two dehydration steps; the dehydration of water molecules physisorbed at the external surface of the crystallites, and the dehydration of intercalated water molecules more strongly attached to hydrogen bonds. Figure 3(b) shows that the derivative thermogravimetric
(DTG) curve for BC also has two steps. The first denotes the oxidation of organic compounds and the differential thermal analysis (DTA) curve indicates an exothermic process. The second peak may be attributed to the oxidation of cellulose and bonding of organic molecules. Figure 3(c) shows that the DTG curve for CuAlLDH@BC shows a similar decomposition and weight loss curve for both materials. 

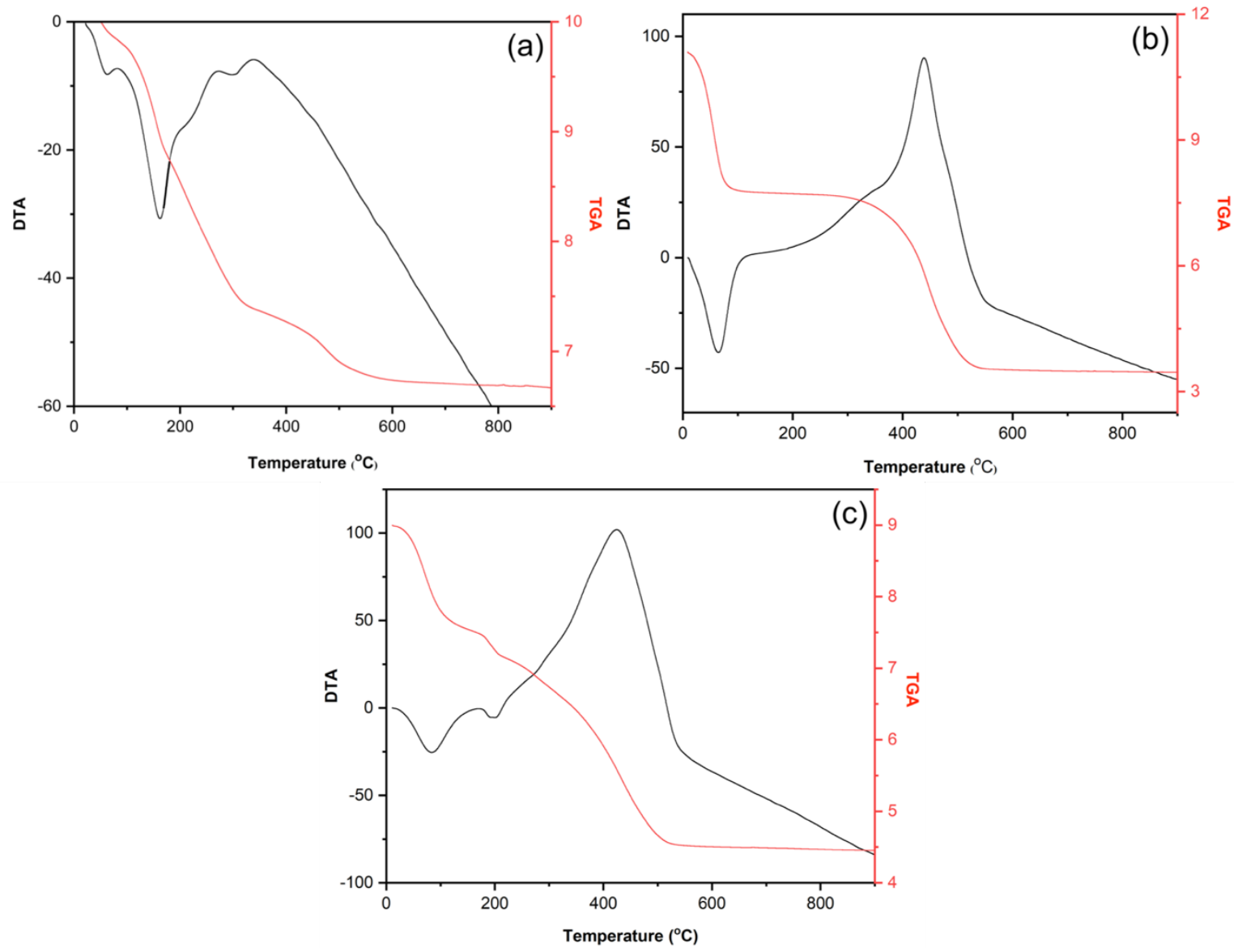

FIGURE 3. Thermogravimetry curve of (a) CuAl LDH, (b) BC, (c) CuAl-LDH@BC composite

The morphologies of CuAl-LDH, BC, and CuAlLDH@BC were investigated and the results are shown in Figure 4. CuAl LDH is characterized by heterogeneity with a round shape and aggregated particles on the surface. This is similar to the morphology reported by Mao and Jiao (2018), who attributed the aggregated morphology to high temperatures during the synthesis process. According to Bukhtiyarova (2019) and Parida and Mohapatra (2012), co-precipitation synthesis of LDH resulted in a plate-like morphology with agglomerated particles on the surface. Figure 4(c) shows that the surface morphology of CuAlLDH@BC has no particular BC-like structure and predominantly shows the presence of the LDH phase.

\section{EFFECT OF CONTACT TIME ON CR REMOVAL}

The effect of contact time on $\mathrm{CR}$ removal by $\mathrm{CuAl}$ $\mathrm{LDH}, \mathrm{BC}$, and $\mathrm{CuAlLDH} @ \mathrm{BC}$ are depicted in Figure 5.
The effect of contact time on $\mathrm{CR}$ adsorption onto $\mathrm{CuAl}$ LDH, BC, and CuAlLDH@BC showed the rapid diffusion of adsorbate molecule in mixing solution with active sites of adsorbent within $40 \mathrm{~min}$. Thus, the adsorption interaction becomes gradual after equilibrium is reached.CuAl-LDH,BC, and CuAlLDH@BC reached equilibrium at 100,70 and $40 \mathrm{~min}$, respectively. The increased adsorption capacity was attributed to the driving force of the concentration gradient. The CR adsorption rate is associated with the interaction of adsorbate and adsorbent's surface. These findings indicated that a low adsorption rate is associated with the internal surface diffusion and pore-filling behavior. The kinetic model of CR removal by various adsorbents is also shown in Figure 5. 


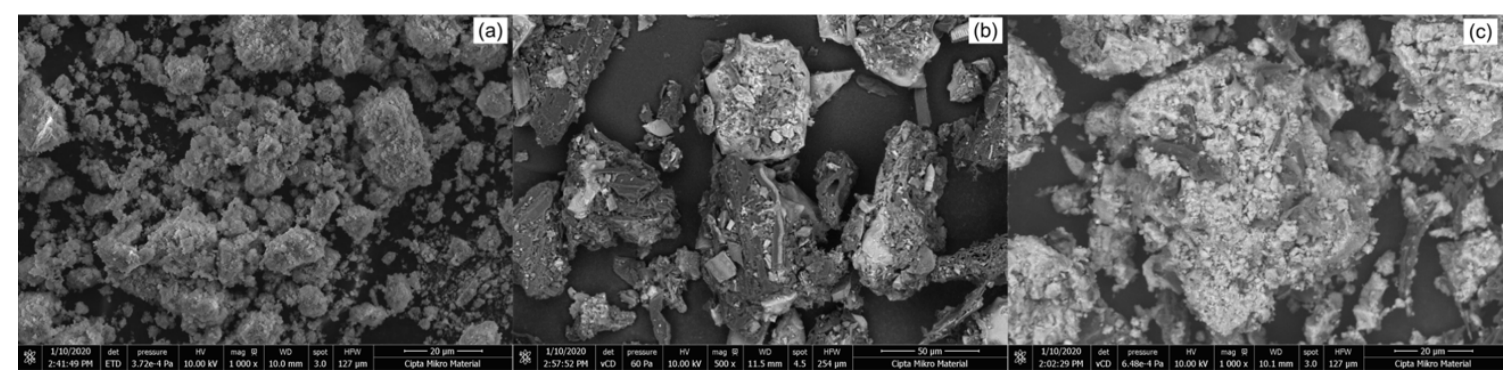

FIGURE 4. SEM images of (a) CuAl LDH, (b) BC, (c) CuAl-LDH@BC composite

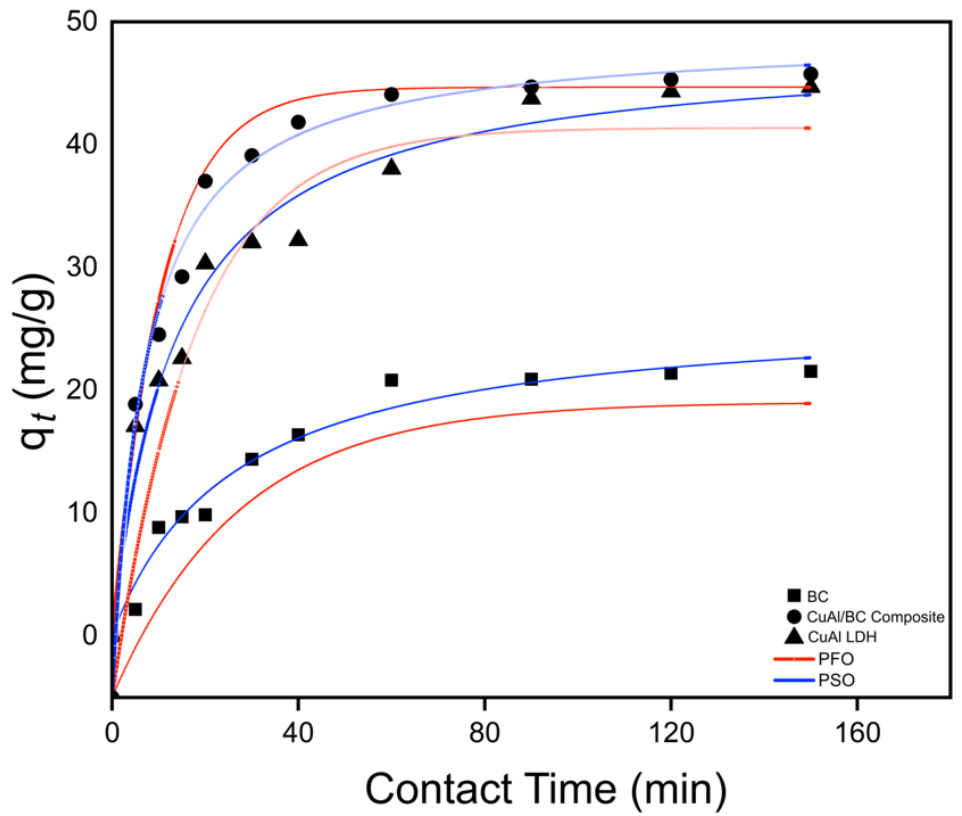

FIGURE 5. The curve of fitted kinetics model against the experimental data by CuAl LDH, BC, and CuAl-LDH@BC composite

Adsorption kinetics were investigated using pseudo-first order (PFO) and pseudo-second-order (PSO) models to predict the process mechanism for adsorbents. The PFO and PSO equations can be expressed by (1) and (2), respectively:

$$
\log (q e-q t)=\log q e-\frac{k_{1} t}{2.303}
$$

$$
\frac{t}{q t}=\frac{1}{k_{2} q e^{2}}+\frac{1}{q e} t
$$

where $\mathrm{q}_{\mathrm{e}}$ and $\mathrm{q}_{\mathrm{t}}$ represent the adsorption capacity at equilibrium and time; $k_{1}$ is the PFO rate constant; and $k_{2}$ is the PSO rate constant. Rate constants were obtained by plotting the equations to derive the correlation coefficients, and are listed in Table 2.

TABLE 2. Summary data for pseudo-first-order (PFO) and pseudo-second-order (PSO) kinetic models fitted to Congo red (CR) adsorption by CuAl-LDh, BC, and CuAlLDH@BC

\begin{tabular}{lccccccc}
\hline \multicolumn{1}{c}{ Adsorbent } & $\mathrm{Qe}_{\text {experiment }}(\mathrm{mg} / \mathrm{g})$ & $\mathrm{Qe}_{\text {Calc }}(\mathrm{mg} / \mathrm{g})$ & $\mathrm{R}^{2}$ & $k_{1}$ & $\mathrm{Qe}_{\text {Calc }}(\mathrm{mg} / \mathrm{g})$ & $\mathrm{R}^{2}$ & $k_{2}$ \\
\hline $\mathrm{CuAlLDH} @ \mathrm{BC}$ & 46.143 & 24.400 & 0.988 & 0.037 & 47.619 & 0.998 & 0.097 \\
$\mathrm{CuAl} \mathrm{LDH}$ & 44.705 & 39.763 & 0.974 & 0.038 & 49.261 & 0.995 & 0.007 \\
$\mathrm{BC}$ & 21.450 & 14.160 & 0.975 & 0.047 & 27.173 & 0.992 & 0.016 \\
\hline
\end{tabular}


The parameters and correlation coefficients $\left(\mathrm{R}^{2}\right)$ obtained from linear plotting of $\log (\mathrm{qe}-\mathrm{qt})$ versus $\mathrm{t}(\mathrm{PFO})$ and $\mathrm{t} / \mathrm{qt}$ versus $\mathrm{t}$ (PSO) are shown in Table 2. In all cases, $\mathrm{R}^{2}>0.992$ and results indicate that PSO is preferred over PFO. According to PSO model assumption, the adsorption rate-controlling steps can be attributed to the chemisorption process. This is further supported by the PSO $\mathrm{qe}_{\text {(calc) }}$, which is close to the $\mathrm{qe}_{\text {(experiment) }}$. These findings indicate that adsorption which suggests electrostatic attraction from adsorbate-adsorbent mixing. The increased $k_{2}$ value of the CuAlLDH@BC composite reflects the reduced time needed by the systems to achieve equilibrium. In other words, a higher $k_{2}$ value indicates that the adsorbate molecule is in a reactive condition (Nisar et al. 2016).

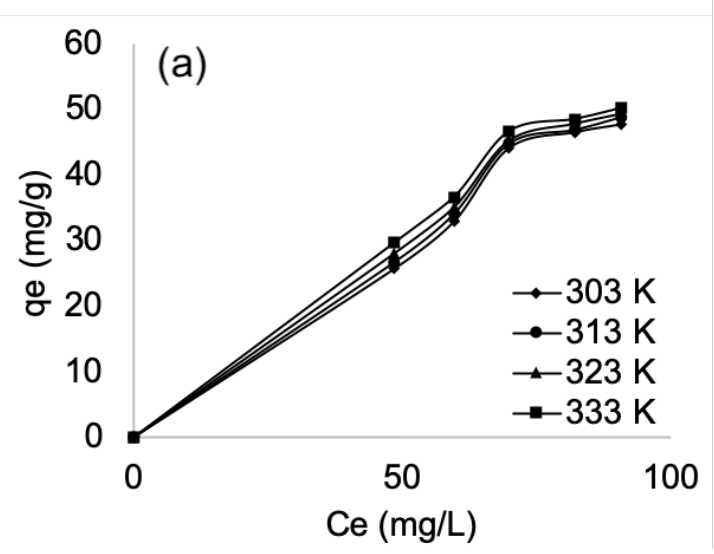

\section{EFFECT OF TEMPERATURE AND ISOTHERM ADSORPTION}

The effect of temperature and the initial concentration of $\mathrm{CR}$ on dye uptake was evaluated for CuAl-LDH, $\mathrm{BC}$, and CuAlLDH@BC. Temperature was investigated between 303 - 333 K. Figure 6(a) represents the CR uptake for several concentrations of CuAl-LDH. The highest CR removal $(49.31 \mathrm{mg} / \mathrm{g})$ was observed at 333 $\mathrm{K}$ and a CuAl-LDH concentration of $90 \mathrm{mg} / \mathrm{L}$. Figure 6(b) shows the highest CR uptake $(32.08 \mathrm{mg} / \mathrm{g})$ by BC was at $333 \mathrm{~K}$ and Figure 6(c) shows that the highest CR uptake $(58.76 \mathrm{mg} / \mathrm{g})$ by the composite was also at $333 \mathrm{~K}$. Increased dye uptake with temperature can be attributed to decreased viscosity of the solution and increased porosity of the interlayer, resulting in the enhancement of active adsorbent sites.

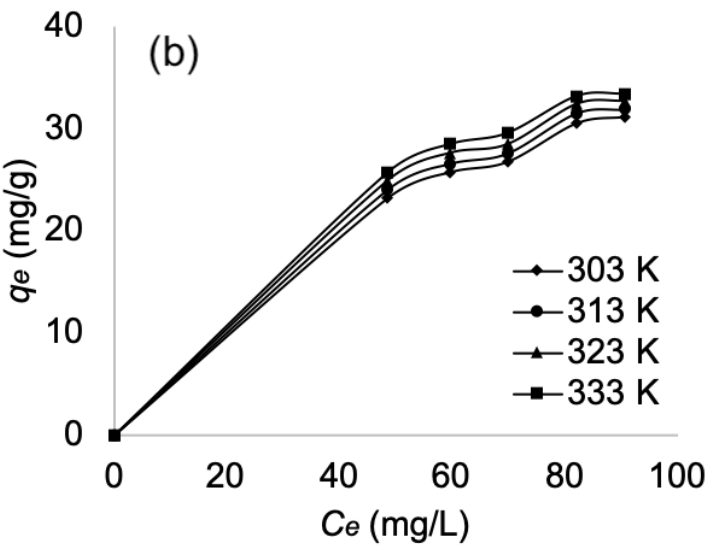

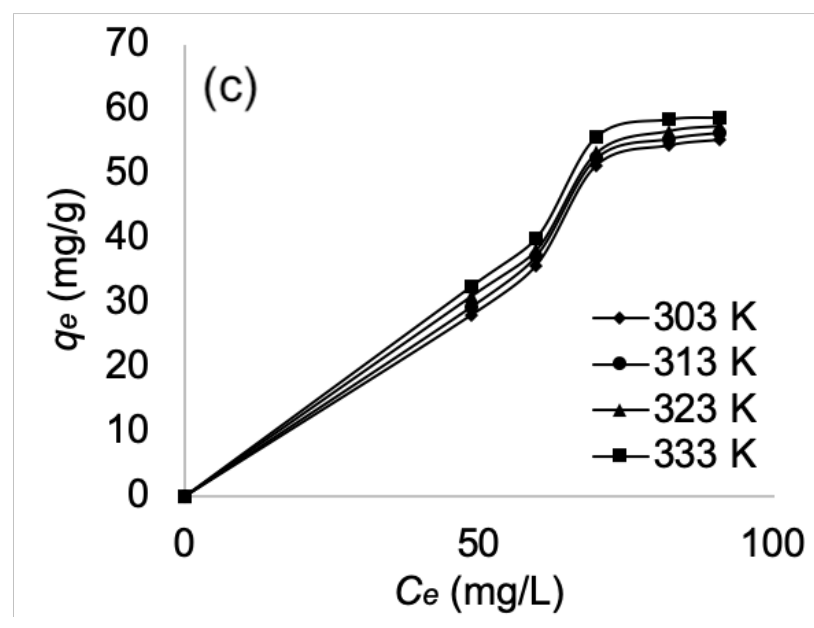

FIGURE 6. Effect of initial temperature of CR adsorption onto CuAl LDH (a), BC (b), CuAl LDH@BC composite (c) 
The adsorption isotherm models are important to describe the adsorption mechanism for $\mathrm{CR}$ interaction on adsorbent surface. The equilibrium studies are useful to obtain the adsorption capacity of $\mathrm{CR}$ adsorption using CuAl-LDH, BC, and CuAlLDH@BC. The equilibrium isotherm model was tested is Freundlich and Langmuir. The Freundlich isotherm adsorption model usually describes a multilayer process on a heterogeneous surface and the Langmuir isotherm describes the interaction of adsorbent-adsorbate and the extent to which a layer or site is occupied on the homogeneous surface (Boutemak et al. 2019). The linear forms of the Langmuir and Freundlich isotherm models can be expressed by (3) and (4), respectively:

$$
\frac{C e}{q e}=\frac{1}{q_{\max }} C_{e}+\frac{1}{q_{\max k_{L}}}
$$

$$
\ln \mathrm{q}_{\mathrm{e}}=\ln k_{F}+\frac{1}{n} \ln \mathrm{C}_{\mathrm{e}}
$$

where $\mathrm{q}_{\max }$ and $k_{L}$ represent Langmuir constant and $k_{F}$ and $\mathrm{n}$ are Freundlich constants with $\mathrm{n}$ providing an indication of a favorable adsorption process and to verify the type of adsorption. The isotherm adsorption parameters are shown in Table 3. In all cases, results show that the $\mathrm{R}^{2}$ for the Langmuir model is higher than those of the Freundlich model, suggesting that $\mathrm{CR}$ adsorption is monolayer adsorption. The maximum adsorption capacities of CuAlLDH, BC, and CuAlLDH@BC were $56.818,42.735$, and $61.350 \mathrm{mg} / \mathrm{g}$, respectively. Similar results of $\mathrm{CR}$ adsorption using several adsorbents have been reported by previous researches. According to Sriram et al. (2019), CR adsorption using diatomaceous earth (DE) obtained an adsorption capacity $23.2 \mathrm{mg} / \mathrm{g}$ at

\begin{tabular}{|c|c|c|c|c|c|c|}
\hline \multirow{2}{*}{ Adsorbent } & \multirow{2}{*}{$\begin{array}{l}\text { Adsorption } \\
\text { isotherm }\end{array}$} & \multirow{2}{*}{$\begin{array}{c}\text { Adsorption } \\
\text { constant }\end{array}$} & \multicolumn{4}{|c|}{$\mathrm{T}(\mathrm{K})$} \\
\hline & & & 303 & 313 & 323 & 333 \\
\hline \multirow[t]{6}{*}{ CuAlLDH@BC } & Langmuir & $\mathrm{Q}_{\text {max }}$ & 60.241 & 60.976 & 62.500 & 61.350 \\
\hline & & $\mathrm{k}_{\mathrm{L}}$ & 0.034 & 0.053 & 0.092 & 0.234 \\
\hline & & $\mathrm{R}^{2}$ & 0.999 & 0.999 & 0.999 & 0.999 \\
\hline & Freundlich & $\mathrm{n}$ & 1.393 & 1.459 & 1.921 & 3.183 \\
\hline & & $\mathrm{k}_{\mathrm{F}}$ & 2.655 & 3.966 & 6.925 & 11.844 \\
\hline & & $\mathrm{R}^{2}$ & 0.998 & 0.986 & 0.999 & 0.995 \\
\hline \multirow[t]{6}{*}{ CuAl-LDH } & Langmuir & $\mathrm{Q}_{\text {max }}$ & 54.348 & 56.180 & 56.556 & 56.818 \\
\hline & & $\mathrm{k}_{\mathrm{L}}$ & 0.167 & 0.156 & 0.159 & 0.218 \\
\hline & & $\mathrm{R}^{2}$ & 0.999 & 0.998 & 0.999 & 0.998 \\
\hline & Freundlich & $\mathrm{n}$ & 0.759 & 0.873 & 0.981 & 1.199 \\
\hline & & $\mathrm{k}_{\mathrm{F}}$ & 2.359 & 1.246 & 1.321 & 2.610 \\
\hline & & $\mathrm{R}^{2}$ & 0.994 & 0.986 & 0.993 & 0.990 \\
\hline \multirow[t]{6}{*}{$\mathrm{BC}$} & Langmuir & $\mathrm{Q}_{\max }$ & 40.537 & 42.918 & 41.112 & 42.735 \\
\hline & & $\mathrm{k}_{\mathrm{L}}$ & 0.044 & 0.031 & 0.057 & 0.064 \\
\hline & & $\mathrm{R}^{2}$ & 0.979 & 0.990 & 0.982 & 0.989 \\
\hline & Freundlich & $\mathrm{n}$ & 2.820 & 1.427 & 1.159 & 1.263 \\
\hline & & $\mathrm{k}_{\mathrm{F}}$ & 7.323 & 2.734 & 1.943 & 2.690 \\
\hline & & $\mathrm{R}^{2}$ & 0.959 & 0.990 & 0.962 & 0.958 \\
\hline
\end{tabular}

TABLE 3. Isotherm adsorption parameters of $\mathrm{CR}$ adsorption using $\mathrm{CuAl} \mathrm{LDH}, \mathrm{BC}$ and CuAlLDH@BC 
pH 7. Lafi et al. (2016) have been reported that CR adsorption using MgAl LDH obtained $60.813 \mathrm{mg} / \mathrm{g}$ after shaken $180 \mathrm{~min}$ from an initial concentration was 120 $\mathrm{mg} / \mathrm{L} . \mathrm{MgFe}$-carbonate is also reported as adsorbent of CR from aqueous solution. The result of adsorption capacity is $104.60 \mathrm{mg} / \mathrm{g}$ at $\mathrm{pH} 4$ (Ahmed et al. 2020). NiCo2O4$\mathrm{NiO}$ has been studied to remove $\mathrm{CR}$ in the aqueous phase, NiCo LDH modified using zeolitic imidazolate framework-67 (ZIF-67) by ultrasonic treatment. The adsorption result was showed the high adsorption capacity of up to $543.5 \mathrm{mg} / \mathrm{g}$ ( $\mathrm{Hu}$ et al. 2019). Lian et al. (2009) also reported that Ca-bentonite was prepared to remove CR from wastewater. The adsorption capacity was slightly increased up to $23.25 \mathrm{mg} / \mathrm{g}$, which was higher than bentonite pristine. Coal-based mesoporous modified activated carbons also reported a low adsorption capacity. The adsorption capacity result is $52 \mathrm{mg} / \mathrm{g}$ at $\mathrm{pH} 7.5$ (adsorbent dosage $5 \mathrm{~g}$, initial dye concentration $150 \mathrm{mg} / \mathrm{L}$ ) (Lorenc-Grabowska \& Gryglewicz 2007). On the other side, activated carbon prepared from coir pith has been studied to adsorb CR and has adsorption capacity up to $6.7 \mathrm{mg} / \mathrm{g}$ at $\mathrm{pH} 3$ (Namasivayam \& Kavitha 2002). These adsorption capacity results are very low if it compared to adsorption capacity of LDH's. According to previous results studies, the adsorption capacity of CuAlLDH@BC is middle-high value compared to other adsorbents.

\section{THERMODYNAMIC STUDY}

Thermodynamic parameters, including enthalpy $(\Delta \mathrm{H})$, entropy $(\Delta S)$, and Gibbs energy $(\Delta G)$ were determined using the Van't Hoff formula as shown in (5) and (6):

$$
\begin{aligned}
& \Delta \mathrm{G}=-R T \ln \left(\mathrm{K}_{\mathrm{d}}\right) \\
& \ln \left(\mathrm{K}_{\mathrm{d}}\right)=\frac{\Delta S}{R}-\frac{\Delta H}{R T}
\end{aligned}
$$

where $R$ represents the universal gas constant and $\mathrm{K}_{\mathrm{d}}$ is the adsorption distribution coefficient. The thermodynamic parameters were determined by calculating Van't Hoff linear regression as $1 / T$ vs $\ln \left(\mathrm{K}_{\mathrm{d}}\right)$ as seen in Figure 7. Table 4 lists the values of the thermodynamic parameters based on Figure 7's data. The negative value of $\Delta G$ at various temperatures confirms the spontaneity of the adsorption process and that it is more favorable at higher temperatures. The positive values of $\Delta \mathrm{S}$ for CR adsorption using CuAl-LDH and CuAlLDH@BC correspond to the randomness of the solid-liquid phase interface during the adsorption process. The positive $\Delta H$ indicates that the adsorption process is endothermic, and this is supported by the fact that CR adsorption increases with temperature.

\begin{tabular}{|c|c|c|c|c|c|c|}
\hline Adsorbents & $\mathrm{C}_{\text {initial }}$ & $\mathrm{T}(\mathrm{K})$ & $\mathrm{Q}_{\mathrm{e}}(\mathrm{mg} / \mathrm{g})$ & $\Delta \mathrm{H}(\mathrm{kJ} / \mathrm{mol})$ & $\Delta \mathrm{S}(\mathrm{kJ} / \mathrm{mol})$ & $\Delta \mathrm{G}(\mathrm{kJ} / \mathrm{mol})$ \\
\hline \multirow{4}{*}{$\mathrm{CuAl} \mathrm{LDH}$} & \multirow{12}{*}{$\begin{array}{c}90.698 \\
\mathrm{mg} / \mathrm{L}\end{array}$} & 303 & 51.270 & 39.967 & 0.134 & -0.722 \\
\hline & & 313 & 52.381 & & & -1.556 \\
\hline & & 323 & 53.254 & & & -2.390 \\
\hline & & 333 & 55.714 & & & -3.224 \\
\hline \multirow{4}{*}{ CuAlLDH@BC } & & 303 & 55.190 & 24.545 & 0.083 & -0.752 \\
\hline & & 313 & 56.302 & & & -2.096 \\
\hline & & 323 & 57.413 & & & -3.440 \\
\hline & & 333 & 58.683 & & & -4.784 \\
\hline \multirow{4}{*}{$\mathrm{BC}$} & & 303 & 45.429 & 4.853 & 0.016 & -0.004 \\
\hline & & 313 & 46.778 & & & -0.165 \\
\hline & & 323 & 47.968 & & & -0.325 \\
\hline & & 333 & 49.397 & & & -0.485 \\
\hline
\end{tabular}

TABLE 4. The thermodynamic parameter of CR adsorption using CuAl LDH, BC and CuAlLDH@BC 


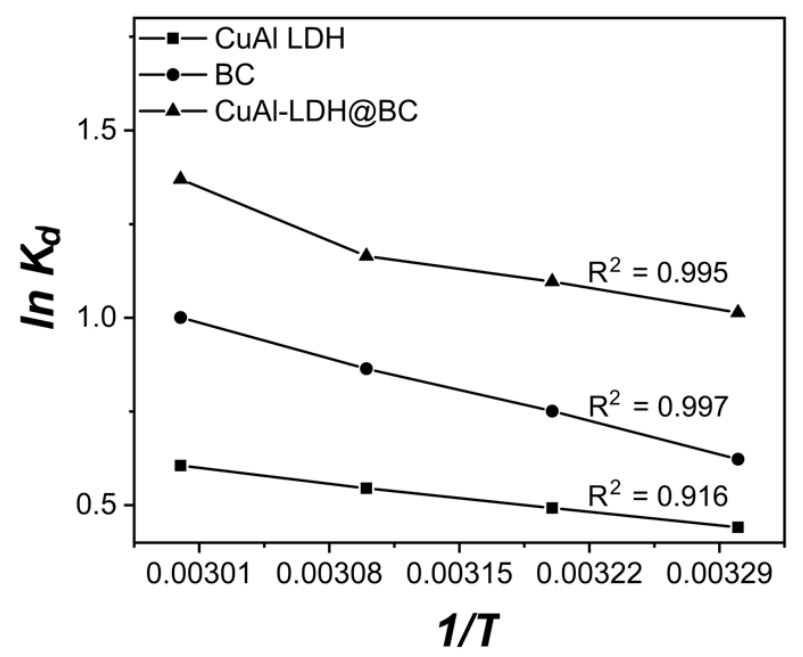

FIGURE 7. Van't Hoff Plot of CR adsorption onto CuAl LDH, BC and CuAl-LDH@BC

\section{DESORPTION AND REUSABILITY}

Desorption was evaluated by contacting the adsorbed dye on the solid surface with water, assuming that the interaction between the adsorbent-adsorbate was weak. Another study regarding adsorbent-adsorbate interaction, the adsorbed dye was desorbed by using $\mathrm{HCl}$, or alcohol i.e. ethanol (Zhang \& Gao 2013). Some eluents were tested in order to get suitable eluent for the desorption process. Figure 8 shows that $\mathrm{HCl}$ becomes suitable eluent for desorption process of $\mathrm{CR}$ onto $\mathrm{CuAl}-\mathrm{LDH}, \mathrm{BC}$ and CuAlLDH@BC with desorption percentage are 98.6, 98.3 and $94.1 \%$, respectively. This finding indicated that in acid condition, the surface of the LDH becoming positively charged so that the electrostatic attraction of adsorbent-adsorbate and H-bonding were weak (Mittal et al. 2009). Furthermore, desorption was also high in the base solution due to hydrophobic interaction and $\mathrm{OH}-$ ions having a higher affinity for the anion exchange. The reusability process leads to determine the effectiveness of the potential adsorbent. The results of the reusability after the three cycles showed slight decreases in the effective adsorption process. Successively, the efficiency of CR removal decreased from 80.93 to $62.60 \%$ for the CuAlLDH@BC composite, from 76.37 to $53.57 \%$ for $\mathrm{CuAl} \mathrm{LDH}$, and from 54.32 to $44.24 \%$ for BC. Thus, in accordance with these results, CuAlLDH@BC composite can be promising as an adsorbent to remove $\mathrm{CR}$.
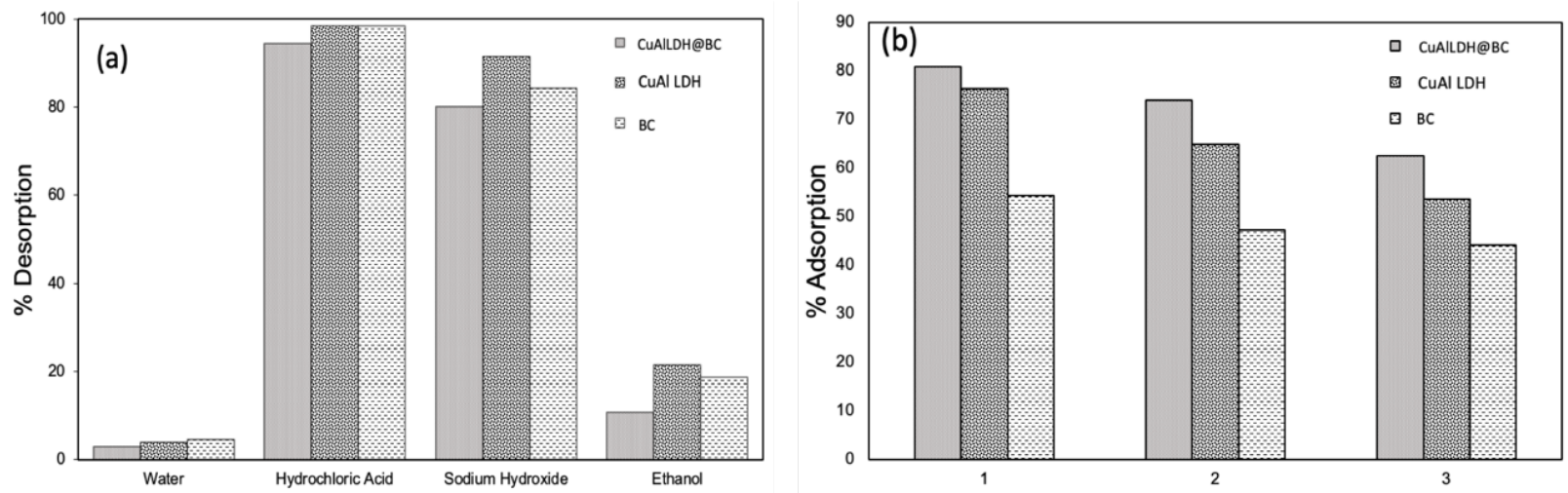

FIGURE 8. (a) CR desorption study and (b) regeneration of adsorbents 


\section{CONCLUSION}

In this study, we prepared a composite based on copper-aluminum and biochar (CuAlLDH@BC) for $\mathrm{CR}$ adsorption. X-ray analysis showed that diffraction peaks of biochar and copper-aluminum layered double hydroxide appeared at $24^{\circ}(002)$ and $10^{\circ}(003), 28^{\circ}$ (006), $35^{\circ}(012), 60^{\circ}(110)$, identical to those of the CuAlLDH@BC composite. The IR spectrum showed that the composite has the vibration of both starting materials at $1645 / \mathrm{cm}$ and $1381 / \mathrm{cm}$. The surface area of CuAlLDH@BC increased markedly to $200.90 \mathrm{~m}^{2} / \mathrm{g}$. Thermal analysis indicated that the patterns of the starting materials also appeared on the composite, as reflected by its heterogeneous shape.

The CuAlLDH@BC composite was used to adsorb $\mathrm{CR}$, and adsorption parameters were determined using kinetic, isotherm, and thermodynamic methods. The PSO kinetic model was fitted for the CuAlLDH@BC composite, and the resulting $\mathrm{q}_{\mathrm{e} \text { calculation }}(47.619 \mathrm{mg} / \mathrm{g})$ was close to the $\mathrm{q}_{\mathrm{e} \text { experiment }}(46.143 \mathrm{mg} / \mathrm{g})$. Adsorption isotherm data suggested that adsorption followed the Langmuir model via monolayer adsorption processes with a maximum capacity of $61.350 \mathrm{mg} / \mathrm{g}$ for CuAlLDH@ $\mathrm{BC}$ at $333 \mathrm{~K}$. This capacity was larger than composite source materials; BC and CuAl-LDH demonstrated maximum adsorption capacities of 42.735 and 56.818 $\mathrm{mg} / \mathrm{g}$ at $333 \mathrm{~K}$, respectively. Thermodynamic analysis indicated that adsorption was spontaneous $(\Delta \mathrm{S}>0)$ and endothermic $(\Delta G<0)$ for all adsorbents. The reusability efficiency concluded that the adsorption capacity of CuAlLDH@BC composite exceeded from 80.93 to $62.60 \%$ following three reusability cycles. We conclude that the composite is a high efficiency and reusable adsorbent for the removal of $\mathrm{CR}$ from an aqueous solution.

\section{ACKNOWLEDGEMENTS}

This study was supported 'Hibah Profesi' Universitas Sriwijaya in fiscal year 2019-2021 by the financial support program for research with contract number 0014/UN9/ SK.LP2M.PT/2019. Special thanks to Research Centre of Inorganic Materials and Complexes FMIPA Universitas Sriwijaya for supporting analysis and instruments.

\section{REFERENCES}

Abdelrahman, E.A. 2018. Synthesis of zeolite nanostructures from waste aluminum cans for efficient removal of malachite green dye from aqueous media. Journal of Molecular Liquids 253(2017): 72-82.
Ahmed, D.N., Naji, L.A., Faisal, A.A.H., Al-Ansari, N. \& Naushad, M. 2020. Waste foundry sand/MgFe-layered double hydroxides composite material for efficient removal of Congo red dye from aqueous solution. Scientific Reports 10(1): 1-12.

Azargohar, R. \& Dalai, A.K. 2006. Biochar as a precursor of activated carbon. Applied Biochemistry and Biotechnology. In Twenty-Seventh Symposium on Biotechnology for Fuels and Chemicals 131(1-3): 762-773.

Boutemak, K., Taoualit, N., Cheknane, B., Laslouni, O., Djeddou, S., Medaoud, K., Mazouni, I. \& Aoudj, S. 2019. Equilibirium, kinetic and thermodynamic study of green malachite and rhodamine-B dyes sorption on olive pomace. Chemical Engineering Transactions 73: 277-282.

Bukhtiyarova, M.V. 2019. A review on effect of synthesis conditions on the formation of layered double hydroxides. Journal of Solid State Chemistry 269: 494-506.

Callister, J.W.D. 2000. Materials Science and Engineering: An Introduction. 5th ed. New York: John Wiley \& Sons.

Chakraborty, P. \& Nagarajan, R. 2015. Efficient adsorption of malachite green and Congo red dyes by the surfactant (DS) intercalated layered hydroxide containing $\mathrm{Zn}^{2+}$ and $\mathrm{Y}^{3+}$-ions. Applied Clay Science 118: 308-315.

Cui, J., Zhang, F., Li, H., Cui, J., Ren, Y. \& Yu, X. 2020. Recent progress in biochar-based photocatalysts for wastewater treatment: Synthesis, mechanisms, and applications. Applied Sciences 10(3): 1019.

Firdaus, M.L., Krisnanto, N., Alwi, W., Muhammad, R. \& Serunting, M.A. 2017. Adsorption of textile dye by activated carbon made from rice straw and oil palm midrib. Aceh International Journal of Science and Technology 6(1): 1.

Foroutan, R., Mohammadi, R., Razeghi, J. \& Ramavandi, B. 2019. Performance of algal activated carbon $/ \mathrm{Fe}_{3} \mathrm{O}_{4}$ magnetic composite for cationic dyes removal from aqueous solutions. Algal Research 40: 101509.

Gholami, P., Khataee, A., Soltani, R.D.C., Dinpazhoh, L. \& Bhatnagar, A. 2020. Photocatalytic degradation of gemifloxacin antibiotic using Zn-Co-LDH@biochar nanocomposite. Journal of Hazardous Materials 382 : 121070 .

Hu, H., Liu, J., Xu, Z., Zhang, L., Cheng, B. \& Ho, W. 2019. Hierarchical porous Ni/Co-LDH hollow dodecahedron with excellent adsorption property for Congo red and $\mathrm{Cr}(\mathrm{VI})$ ions. Applied Surface Science 478: 981-990.

Huang, D., Liu, C., Zhang, C., Deng, R., Wang, R., Xue, W., Luo, H., Zheng, G., Zhang, Q. \& Guo, X. 2019. Cr(VI) removal from aqueous solution using biochar modified with $\mathrm{Mg} / \mathrm{Al}$-layered double hydroxide intercalated with ethylenediaminetetraacetic acid. Bioresource Technology 276: 127-132.

Inumaru, K., Ishihara, T., Kamiya, Y., Okuhara, T. \& Yamanaka, S. 2007. Water-tolerant, highly active solid acid catalysts composed of the keggin-type polyoxometalate H3PW12O40 immobilized in hydrophobic nanospaces of organomodified mesoporous silica. Angewandte Chemie - International Edition 46(40): 7625-7628. 
Lafi, R., Charradi, K., Djebbi, M.A., Ben Haj Amara, A. \& Hafiane, A. 2016. Adsorption study of Congo red dye from aqueous solution to $\mathrm{Mg}$-Al-layered double hydroxide. Advanced Powder Technology 27(1): 232-237.

Lesbani, A., Taher, T., Palapa, N.R., Mohadi, R., Rachmat, A. \& Mardiyanto. 2020. Preparation and utilization of Keggintype polyoxometalate intercalated $\mathrm{Ni}-\mathrm{Fe}$ layered double hydroxides for enhanced adsorptive removal of cationic dye. SN Applied Sciences 2: 470.

Lian, L., Guo, L. \& Guo, C. 2009. Adsorption of Congo red from aqueous solutions onto Ca-bentonite. Journal of Hazardous Materials 161(1): 126-131.

Lorenc-Grabowska, E. \& Gryglewicz, G. 2007. Adsorption characteristics of Congo Red on coal-based mesoporous activated carbon. Dyes and Pigments 74(1): 34-40.

Ma, J., Ding, J., Yu, L., Li, L., Kong, Y. \& Komarneni, S. 2015. $\mathrm{BiOCl}$ dispersed on NiFe-LDH leads to enhanced photodegradation of Rhodamine B dye. Applied Clay Science 109-110: 76-82.

Mahjoubi, F.Z., Elhalil, A., Elmoubarki, R., Sadiq, M., Khalidi, A., Cherkaoui, O. \& Barka, N. 2017. Performance of Zn - , $\mathrm{Mg}$ - and Ni - Al layered double hydroxides in treating an industrial textile wastewater. Journal of Applied Sciences and Interfaces 2(1-3): 1-11.

Malak-Polaczyk, A., Vix-Guterl, C. \& Frackowiak, E. 2010. Carbon/layered double hydroxide (LDH) composites for supercapacitor application. Energy and Fuels 24(6): 33463351.

Mao, N. \& Jiao, Y. 2018. CuAl hydrotalcite formed CuAl-Mixed metal oxides for photocatalytic removal of rhodamine B and Cr(VI). ChemistrySelect 3(44): 12676-12681.

Meili, L., Lins, P.V., Zanta, C.L.P.S., Soletti, J.I., Ribeiro, L.M.O., Dornelas, C.B., Silva, T.L. \& Vieira, M.G.A. 2019. MgA1$\mathrm{LDH} /$ Biochar composites for methylene blue removal by adsorption. Applied Clay Science 168: 11-20.

Mittal, A., Mittal, J., Malviya, A. \& Gupta, V.K. 2009. Adsorptive removal of hazardous anionic dye "Congo red" from wastewater using waste materials and recovery by desorption. Journal of Colloid And Interface Science 340(1): 16-26.

Mohammed, M.I. \& Baytak, S. 2016. Synthesis of bentonitecarbon nanotube nanocomposite and its adsorption of rhodamine dye from water. Arabian Journal for Science and Engineering 41(12): 4775-4785.

Namasivayam, C. \& Kavitha, D. 2002. Removal of Congo Red from water by adsorption onto activated carbon prepared from coir pith, an agricultural solid waste. Dyes and Pigments 54(1): 47-58.

Nisar, J., Sayed, M., Ullah, F., Mahmood, H., Iqbal, M., Ali, R. \& Anas, M. 2016. Gamma - irradiation induced degradation of diclofenac in aqueous solution: Kinetics, role of reactive species and influence of natural water parameters. Biochemical Pharmacology 4(2): 2573-2584.

Palapa, N.R., Juleanti, N., Normah, N., Taher, T. \& Lesbani, A. 2020a. Unique adsorption properties of malachite green on interlayer space of $\mathrm{Cu}-\mathrm{Al}$ and $\mathrm{Cu}-\mathrm{Al}-\mathrm{SiW} 12 \mathrm{O} 40$ layered double hydroxides. Bulletin of Chemical Reaction Engineering \& Catalysis 15(3): 653-661.

Palapa, N.R., Mohadi, R., Rachmat, A. \& Lesbani, A. 2020 b. Adsorption study of malachite green removal from aqueous solution using $\mathrm{Cu} / \mathrm{M}^{3+}\left(\mathrm{M}^{3+}=\mathrm{Al}, \mathrm{Cr}\right)$ layered double hydroxide. Mediterranean Journal of Chemistry 10(1): 33-45.

Parida, K.M. \& Mohapatra, L. 2012. Carbonate intercalated $\mathrm{Zn} / \mathrm{Fe}$ layered double hydroxide: a novel photocatalyst for the enhanced photo degradation of azo dyes. Chemical Engineering Journal 179: 131-139.

Patterson, R.F. \& Savas, E. 2016. On P-convergence of four dimensional weighted sums of double random variables. Sains Malaysiana 45(7): 1177-1181.

Peng, C., Dai, J., Yu, J. \& Yin, J. 2015. Calcined Mg-Fe layered double hydroxide as an absorber for the removal of methyl orange. AIP Advances 5(5): 057138.

Raval, N.P., Shah, P.U. \& Shah, N.K. 2016. Adsorptive amputation of hazardous azo dye Congo red from wastewater: A critical review. Environmental Science and Pollution Research 23(15): 14810-14853.

Schwarzenbach, R.P., Egli, T., Hofstetter, T.B., von Gunten, U. \& Wehrli, B. 2010. Global water pollution and human health. Annual Review of Environment and Resources 35(1): 109-136.

Shenvi, S.S., Isloor, A.M., Ismail, A.F., Shilton, S.J. \& Al Ahmed, A. 2015. Humic acid based biopolymeric membrane for effective removal of methylene blue and rhodamine $\mathrm{b}$. Industrial and Engineering Chemistry Research 54(18): 4965-4975.

Soleimani, K., Tehrani, A.D.D. \& Adeli, M. 2018. Bioconjugated graphene oxide hydrogel as an effective adsorbent for cationic dyes removal. Ecotoxicology and Environmental Safety 147: $34-42$.

Sriram, G., Uthappa, U.T., Kigga, M., Jung, H.Y., Altalhi, T., Brahmkhatri, V. \& Kurkuri, M.D. 2019. Xerogel activated diatoms as an effective hybrid adsorbent for the efficient removal of malachite green. New Journal of Chemistry 43(9): 3810-3820.

Thommes, M., Kaneko, K., Neimark, A.V., Olivier, J.P., Rodriguez-Reinoso, F., Rouquerol, J. \& Sing, K.S.W. 2015. Physisorption of gases, with special reference to the evaluation of surface area and pore size distribution. Pure and Applied Chemistry 87(9-10): 1051-1069.

Tran, H.N., Lin, C.C., Woo, S.H. \& Chao, H.P. 2018. Efficient removal of copper and lead by $\mathrm{Mg} / \mathrm{Al}$ layered double hydroxides intercalated with organic acid anions: Adsorption kinetics, isotherms, and thermodynamics. Applied Clay Science 154: 17-27.

Vikrant, K., Giri, B.S., Raza, N., Roy, K., Kim, K.H., Rai, B.N. \& Singh, R.S. 2018. Recent advancements in bioremediation of dye: Current status and challenges. Bioresource Technology 253: 355-367.

Wang, S., Gao, B., Li, Y., Zimmerman, A.R. \& Cao, X. 2016. Sorption of arsenic onto $\mathrm{Ni} / \mathrm{Fe}$ layered double hydroxide (LDH)-biochar composites. RSC Advances 6(22): 1779217799. 
Wu, X.L., Wang, L., Chen, C.L., Xu, A.W. \& Wang, X.K. 2011. Water-dispersible magnetite-graphene-LDH composites for efficient arsenate removal. Journal of Materials Chemistry 21(43): 17353-17359.

Xia, Y., Yang, T., Zhu, N., Li, D., Chen, Z., Lang, Q., Liu, Z. \& Jiao, W. 2019. Enhanced adsorption of Pb(II) onto modified hydrochar: Modeling and mechanism analysis. Bioresource Technology 288: 1-8.

Zainol, M.M., Amin, N.A.S. \& Asmadi, M. 2017. Preparation and characterization of impregnated magnetic particles on oil palm frond activated carbon for metal ions removal. Sains Malaysiana 46(5): 773-782.

Zhang, M. \& Gao, B. 2013. Removal of arsenic, methylene blue, and phosphate by biochar/AlOOH nanocomposite. Chemical Engineering Journal 226: 286-292.

Zhu, Z., Ouyang, S., Li, P., Shan, L., Ma, R. \& Zhang, P. 2020. Persistent organic pollutants removal via hierarchical flowerlike layered double hydroxide: Adsorption behaviors and mechanism investigation. Applied Clay Science 188: 105500.

Zubair, M., Manzar, M.S., Mu'azu, N.D., Anil, I., Blaisi, N.I. \& Al-Harthi, M.A. 2020. Functionalized MgAl-layered hydroxide intercalated date-palm biochar for enhanced uptake of cationic dye: Kinetics, isotherm and thermodynamic studies. Applied Clay Science 190: 105587.

Neza Rahayu Palapa \& Aldes Lesbani*

Graduate School, Faculty of Mathematics and Natural Sciences Universitas Sriwijaya

Jl. Palembang-Prabumulih, Km. 32

Ogan Ilir, South Sumatera

Indonesia
Novie Juleanti, Normah \& Aldes Lesbani*

Research Center of Inorganic Materials and Complexes

Faculty of Mathematics and Natural Sciences

Universitas Sriwijaya

Jl. Padang Selasa Bukit Besar Palembang

30139 South Sumatera

Indonesia

Tarmizi Taher

Department of Environmental Engineering

Institut Teknologi Sumatera

Jalan Terusan Ryacudu, Way Hui

Kecamatan Jati Agung

Lampung Selatan 35365

Indonesia

Risfidian Mohadi \& Addy Rachmat

Department of Chemistry

Faculty of Mathematics and Natural Sciences

Universitas Sriwijaya

Jl. Palembang-Prabumulih, Km. 32

Ogan Ilir, South Sumatera

Indonesia

*Corresponding author; email: aldeslesbani@pps.unsri.ac.id

Received: 7 February 2021

Accepted: 22 April 2021 